\title{
An antibiotic loaded ceramic sternum to treat destroyed infected sternum: 4 cases
}

\author{
Jeremy Tricard ${ }^{1}$, Anaëlle Chermat ${ }^{1}$, Souleiman El Balkhi ${ }^{2}$, Eric Denes ${ }^{3,4}$, François Bertin ${ }^{1}$ \\ ${ }^{1}$ Thoracic and Cardiovascular Surgery Department, Limoges Teaching Hospital, Limoges, France; ${ }^{2}$ Pharmacology Department, Limoges Teaching \\ Hospital, Limoges, France; ${ }^{3}$ R\&D Department, I.Ceram, Limoges, France; ${ }^{4}$ Infectious Diseases Department, Polyclinique de Limoges, Limoges, France \\ Contributions: (I) Conception and design: F Bertin, E Denes; (II) Administrative support: E Denes; (III) Provision of study materials or patients: F \\ Bertin, A Chermat, J Tricard; (IV) Collection and assembly of data: E Denes, F Bertin, A Chermat, J Tricard; (V) Data analysis and interpretation: E \\ Denes, S El Balkhi; (VI) Manuscript writing: All authors; (VII) Final approval of manuscript: All authors. \\ Correspondence to: Dr. François Bertin. Thoracic and vascular Surgery department, CHU Dupuytren 2, Avenue Martin Luther King, 87000 Limoges, \\ France. Email: f.bertin@sfctcv.org.
}

Background: After its destruction during refractory deep sternal wound infection (DSWI), current sternum reconstructions mainly rely on muscle flaps technique, but such technique have pitfalls and limits. To tackle the limited possibilities to use device implantation because of the risk of infection, we developed a self-protected device allowing its implantation in an infected area.

Methods: We used gentamicin alone or in combination with vancomycin loaded in a porous ceramic sternum to replace sternums destroyed during DSWI. The aim was to mechanically replace the sternum and to secure the implantation by killing the remaining bacteria in the wound thanks to the loaded antibiotic.

Results: This device was implanted in four infected patients during DWSI with sternal dehiscence. No complication occurred during surgeries, and wound healing was obtained quickly. Local antibiotic concentrations largely exceeded the ones needed for their efficacy while no antibiotic was found in the blood. All patients are well-being. However previously unknown gentamicin resistant bacteria, present in the surgical wound at the time of positioning, required sternal implant removal for one patient after 19 months. For all patients, pulmonary function tests (PFT) improved after implantation.

Conclusions: The ceramic sternum played its role consolidating the thoracic cage without stiffening. The antibiotic loaded in the sternum allowed a secure implantation, killing bacteria before the colonization of the implant even in this infected area. These four implantations are promising for patients with sternal destruction after DSWI.

Keywords: Sternum; deep sternal wound infection (DSWI); alumina; antibiotic loaded; mediastinitis; pulmonary function tests (PFT); ceramic

Submitted Nov 29, 2019. Accepted for publication Jan 10, 2020.

doi: $10.21037 /$ jtd.2020.01.70

View this article at: http://dx.doi.org/10.21037/jtd.2020.01.70

\section{Introduction}

To date, there is no surgical "gold standard" for sternum replacement after its destruction by an infection, such as deep sternal wound infection (DSWI). Vacuum-assisted closure (VAC) therapy is usually used during early stage of healing and a muscle or omental flap is proposed in a second time $(1,2)$. Generally, no foreign body is used due to the risk of infection even if titanium plates seem to be an option for some authors (3). Pitfalls of the muscle flap technic are mostly residual pain, seroma, arm strength loss, chest wall instability and pulmonary function impairment (4-7). To propose a new option for sternal reconstruction during DSWI, the porous structure of an alumina ceramic sternal prosthesis (I.Ceram ${ }^{\circledR}$, Limoges, France) (8) has been loaded 


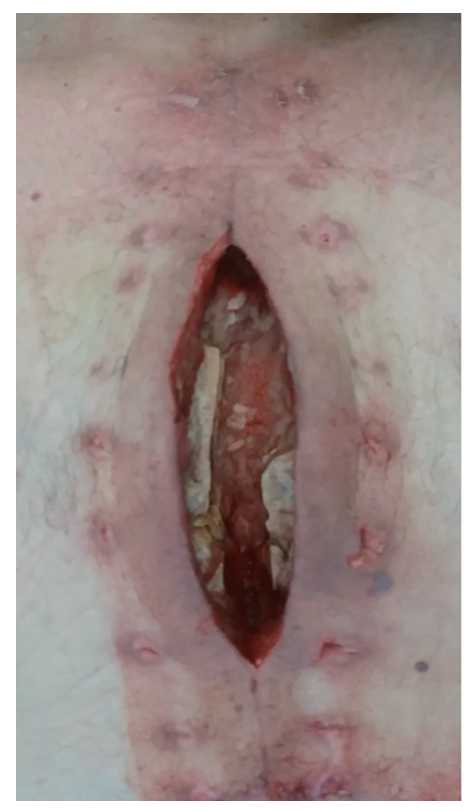

Figure 1 Sternum aspect of patient \#2 before ceramic sternum implantation showing a great destruction and bone loss.

with an antibiotic for a local release and the protection of the implanted device in an infected environment. Indeed, local delivery allows eradicating bacteria present in the wound, avoiding them to colonize the prosthesis. The same type of combined device has already been successfully used for chronic osteomyelitis due to Methicillin Resistant Stapbylococcus aureus (MRSA) (9). Thus, this antibiotic loaded ceramic device combines the possibility of chest wall stabilization and its self-protection during implantation. In this study, we describe the use and the follow-up of this device, including pulmonary function tests (PFT) in four patients.

\section{Methods}

The four patients who received this antibiotic loaded-device suffered from a refractory DSWI. Multiple debridement surgeries and VAC therapy were performed in combination with antibiotic treatments. Unfortunately, they all presented a partial destruction and dehiscence of their sternum (Figure 1). For these reasons, we decided not to use the classical fasciocutaneous flaps. Indeed, we wanted to (I) protect the underlying organs and vessels (II) avoid an instability of the sternum (III) reconstruct the thoracic cage to retrieve the greatest pulmonary function.

Characteristics of patients are summarized in Table 1.
The device is the combination of two compounds. First, a porous ceramic (referred to as "alumina") which has been shaped to replace the sternum (Figure 2) (8). It is made of alumina which is an inert, biocompatible and non-absorbable ceramic $(10,11)$. Chemical composition of alumina is $\mathrm{Al}_{2} \mathrm{O}_{3}$. This material does not interfere with cardiac echography, chest X-ray, CT-Scan or electrocardiogram.

The second compound is an antibiotic. In relation with the local bacterial ecology, the first three patients received a gentamicin loaded sternum and the fourth one a gentamicin-vancomycin loaded sternum.

Gentamicin is a member of the aminoglycosides class and has a broad spectrum activity with a relatively low rate of resistance even for MRSA (12). Its apparent volume of distribution is low $(0.2 \mathrm{~L} / \mathrm{kg})$ meaning that the diffusion in tissues is poor (13). The low local concentrations make the systemic use of gentamicin inefficient to treat tissues infection. Moreover, increasing the doses is not possible due to a low therapeutic index. Indeed, increasing the dose will lead to toxicity, mainly acute kidney failure or ototoxicity. It is usually injected once daily to optimize the maximal concentration, which is the pharmacological parameter that best describes its efficiency. Indeed, the Inhibitory Quotient $\frac{C_{\max }}{M I C}>10$ is the marker of its efficiency $\left(C_{\max }:\right.$ maximal concentration - MIC: minimal inhibitory concentration).

Vancomycin is a member of the glycopeptide class and is active against Gram positive cocci and especially against MRSA. As for gentamicin, its diffusion in mediastinum is poor (14) with a low distribution volume $(0.68 \mathrm{~L} / \mathrm{kg})(13)$. For this antibiotic also, the increase of the administered dose is not an option as acute kidney failure can easily occur. For this antibiotic, the parameter $\frac{A U C}{M I C}>400$ is associated with a successful outcome (AUC: Area Under the Curve) (15). Thus there is a tight link between the MIC, the pharmacodynamics and bacteriological resistance. So, according to European Committee on Antimicrobial Susceptibility Testing (EUCAST 2019) the MIC breakpoint for vancomycin administered intravenously is $4 \mu \mathrm{g} / \mathrm{mL}$ for non-coagulase positive Staphylococci (16). This means that a Methicillin-resistant S. epidermidis (MRSE) with an MIC greater than $4 \mu \mathrm{g} / \mathrm{mL}$ will be considered as resistant.

It has been demonstrated in vitro that both antibiotic release begins quickly, last for $48-72 \mathrm{~h}$ and that $100 \%$ of the dose is released. This in vitro kinetic suggests a sufficient protection in vivo, from the device positioning and for 
Table 1 Characteristics of patients

\begin{tabular}{|c|c|c|c|c|}
\hline Characteristic & \multicolumn{4}{|c|}{ Patient } \\
\hline Sex & Male & Male & Male & Male \\
\hline Age (year) & 68.1 & 77.9 & 53.4 & 71.0 \\
\hline Risk factors & $\begin{array}{l}\text { Type } 2 \text { diabetes, obesity, } \\
\text { COPB, high blood pressure; } \\
\text { smoking ( } 60 \text { pack-year) }\end{array}$ & $\begin{array}{l}\text { Type } 2 \text { diabetes, obesity, } \\
\text { COPB, high blood } \\
\text { pressure }\end{array}$ & $\begin{array}{l}\text { Type } 2 \text { diabetes, } \\
\text { malnutrition, COPB, } \\
\text { smoking ( } 15 \text { pack-year), } \\
\text { chronic alcoholism }\end{array}$ & High blood pressure \\
\hline BMI & 29.8 & 32.6 & 24.0 & 21.7 \\
\hline $\begin{array}{l}\text { Albumin before } \\
\text { implantation }(\mathrm{g} / \mathrm{L})\end{array}$ & 32.4 & 22.3 & 30 & 29.7 \\
\hline Complication & Sternal disunion after DSWI & $\begin{array}{l}\text { Sternal fracture and } \\
\text { disunion after DSWI }\end{array}$ & $\begin{array}{l}\text { Sternal disunion after } \\
\text { DSWI }\end{array}$ & $\begin{array}{l}\text { Sternal disunion after } \\
\text { DSWI }\end{array}$ \\
\hline \multicolumn{5}{|l|}{ Complication management } \\
\hline $\begin{array}{l}\text { Number of debridement } \\
\text { surgeries }\end{array}$ & 2 & 2 & 2 & \\
\hline Bacteriological sample \#1 & E. cloacae; S. haemolyticus & $\begin{array}{l}\text { S. epidermidis }(\mathrm{S}) ; \mathrm{S} \text {. } \\
\text { warneri }(\mathrm{S})\end{array}$ & $\begin{array}{l}\text { S. epidermidis (S); K. } \\
\text { pneumoniae }(\mathrm{S})\end{array}$ & $\begin{array}{l}\text { K. pneumoniae (S); } \\
\text { MRSA (R) and VancoR }\end{array}$ \\
\hline Bacteriological sample \#2 & MRSE (S) & S. epidermidis (S) & S. epidermidis (R) & $\begin{array}{l}\text { K. pneumoniae (S); } \\
\text { MRSA (R) and VancoR }\end{array}$ \\
\hline $\begin{array}{l}\text { Local clinical aspect } \\
\text { before sternal implant } \\
\text { surgery }\end{array}$ & $\begin{array}{l}\text { Open wound with dehiscent } \\
\text { sternum }\end{array}$ & $\begin{array}{l}\text { Open wound with } \\
\text { dehiscent and partially } \\
\text { destroyed sternum }\end{array}$ & $\begin{array}{l}\text { Skin fistula and sternum } \\
\text { parts discharge through } \\
\text { the skin }\end{array}$ & $\begin{array}{l}\text { Open wound with } \\
\text { dehiscent sternum }\end{array}$ \\
\hline \multicolumn{5}{|l|}{ Implantation surgery } \\
\hline Antibiotic loaded & Gentamicin & Gentamicin & Gentamicin & $\begin{array}{l}\text { Gentamicin and } \\
\text { vancomycin }\end{array}$ \\
\hline $\begin{array}{l}\text { Operation time }(\mathrm{min}) \text { - } \\
\text { complete surgery }\end{array}$ & 240 & 240 & 180 & 140 \\
\hline $\begin{array}{l}\text { Bacteriological analyses } \\
\text { from native sternum }\end{array}$ & $\begin{array}{l}\text { K. pneumoniae (S); Veillonella } \\
\text { parvula; Finegoldia magna; } \\
\text { Streptococcus mitis; } \\
\text { S. Iugdunensis (S); S. } \\
\text { epidermidis (R) }\end{array}$ & $\begin{array}{l}\text { S. haemolyticus } \\
\text { (R); S. epidermidis } \\
\text { (R); C. jeikeium (R); } \\
\text { enterococcus faecalis }\end{array}$ & $\begin{array}{l}\text { S. epidermidis (S); S. } \\
\text { epidermidis (R); } E \text {. } \\
\text { cloacae (S) }\end{array}$ & $\begin{array}{l}\text { Sterile, but still } \\
\text { unhealed and pus } \\
\text { issue }\end{array}$ \\
\hline
\end{tabular}

Table 1 (continued) 
Table 1 (continued)

\begin{tabular}{|c|c|c|c|c|c|c|}
\hline Characteristic & \multicolumn{6}{|c|}{ Patient } \\
\hline \multicolumn{7}{|l|}{ Follow-up after implantation } \\
\hline $\begin{array}{l}\text { Time from surgery to } \\
\text { hospital discharge (day) }\end{array}$ & 20 & 24 & 30 & & 25 & \\
\hline Follow-up (months) & 41 & 37 & 20 & & 2 & \\
\hline
\end{tabular}

BMI, body mass index; MRSE, methicillin resistant staphylococcus epidermidis; MRSA, methicillin resistant staphylococcus aureus; (S), gentamicin sensitive; $(\mathrm{R})$, gentamicin resistant; VancoR, vancomycin resistant.

several days after surgical wound closure. The gentamicin loaded dose was $320 \mathrm{mg}$ for patient \#1, \#2 and \#4 and $160 \mathrm{mg}$ for patient \#3 in relation with ceramic sternum size. In addition to gentamicin, $250 \mathrm{mg}$ of vancomycin were present in the device for patient \#4.

The combination of the antibiotics and the ceramic sternum was manufactured by I.Ceram ${ }^{\circledR}$. It was delivered in a dry formulation, ready to use and without additional step during surgical procedure.

The surgical technique was divided in several steps (8). After debridement of the infected area and removal of necrotized tissues (Figure $2 A$ ), trial implants were used to choose the size of the device and to prepare the area for implantation (Figure 2B). Skin and soft tissues were dissected to prepare the final closure. Suture threads were positioned in the ribs and/or cartilages (Figure 2C). Drains are placed as usual for advancement bilateral pectoral flap and over the muscle in regard to the prosthesis. The ceramic prosthesis was placed and anchored without special osteosynthesis equipment (non-absorbable suture threads) (Figure 2D,E). The surgical site was closed (Figure 2F). Drains in regard of the prosthesis are removed after $24 \mathrm{~h}$ and the other are left for about 5 days to avoid seromas.

If needed the device could easily be remove cutting the suture threads and tissues around the device.

All patients received systemic antibiotic treatment as the local delivery is considered as a prophylaxis and not a treatment.

These surgeries were approved by the ethic committee of the Limoges Teaching Hospital and were allowed by the French Agency for Health Security (Agence Nationale de la Sécurité du Médicament et des produits de santé, ANSM). Patients gave their written consent for the use of this device.

\section{Results}

During surgery, implantation and anchoring stages took about 30 minutes, making the reconstruction step shorter than a muscle flap realization. There was no complication during surgeries. For all patients, healing was achieved within 2 weeks after surgery. They all returned home and came back to prior activities. They are all well-being. All bacteriological samples performed before or during implantation surgeries were microbiologically positive (Table 1).

Concerning gentamicin, local samples (for patients \#2, \#3 and \#4) showed very high concentration (Figure 3). $\frac{C_{\max }}{M I C}$ largely exceeded 10 (at least $>1,500$ ). Even for the MRSE (patient \#4) with a MIC of $384 \mu \mathrm{g} / \mathrm{mL}$, the ratio was 17 , allowing gentamicin to be efficient. Concentrations remain high for at least 24 hours (no data after drain removal). For vancomycin, even if the MRSE was considered as resistant, according to EUCAST [MIC: $8 \mu \mathrm{g} / \mathrm{mL}$ Vitex $^{\circledR} 2$ (BioMérieux ${ }^{\circledR}$, Marcy-l’Étoile, France)], this "pharmacological resistance" was over-passed with an $\frac{A U C}{M I C}=16,000$. At the same time, blood concentrations of gentamicin were below the limit of detection, namely $<0.5 \mathrm{mg} / \mathrm{L}$, from 1 hour after implantation until 2 days after surgery for patients \#1, \#3 and \#4. For patient \#2 a very low and non-toxic concentration of $0.6 \mathrm{mg} / \mathrm{L}$ was found after 3 and 6 hours and returned undetectable after. It was the same for vancomycin with blood concentrations below $1.1 \mathrm{mg} / \mathrm{L}$ for patient \#4.

During the follow-up, due to the presence of previously unknown gentamicin-resistant bacteria in the wound of patient \#2 at the time of implantation, the 

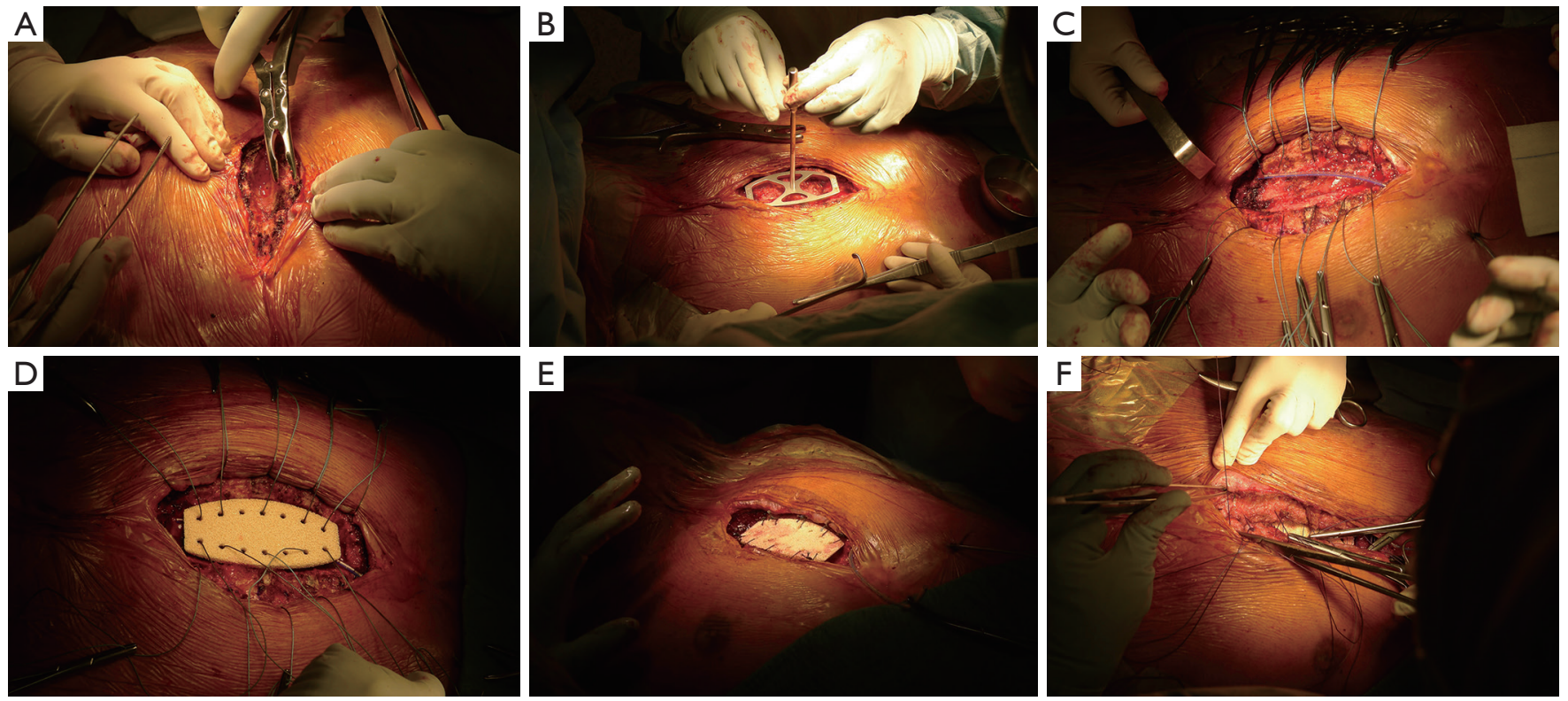

Figure 2 Surgery technique. (A) Debridement of the sternal area; (B) use of the trial implant to choose the appropriate size and to remove parts which could impede implantation; (C) preparation of anchoring with suture threads; (D) prosthesis was then secured to the ribs by size 3 non-absorbable sutures threads using the pre-existing holes; (E) anchoring ending; (F) pedicled pectoral flap and surgical wound closure.

\begin{tabular}{|c|c|c|c|c|}
\hline Patient & & \multicolumn{2}{|c|}{ Local concentrations } & Comparison with pharmacological parameter \\
\hline & & & & $\mathrm{C}_{\max } / \mathrm{MIC}>10$ \\
\hline & Loaded dose & $\mathrm{H} 1$ & $\mathrm{H} 24$ & $\mathrm{H} 1$ \\
\hline \#2 & $320 \mathrm{mg}$ & $1,500 \mathrm{mg} / \mathrm{L}$ & $395 \mathrm{mg} / \mathrm{L}$ & Yes $(>1,500)$ \\
\hline$\# 4$ & $320 \mathrm{mg}$ & $6,560 \mathrm{mg} / \mathrm{L}$ & $4.7 \mathrm{mg} / \mathrm{L}$ & Yes [17] \\
\hline \multicolumn{5}{|c|}{ Vancomycin } \\
\hline & & & & AUC/MIC $>400$ \\
\hline \#4 & $250 \mathrm{mg}$ & $390 \mathrm{mg} / \mathrm{L}$ & $28.1 \mathrm{mg} / \mathrm{L}$ & Yes $[16,000]$ \\
\hline
\end{tabular}

Figure 3 Local concentrations and comparison with MICs. MIC, minimal inhibitory concentration.

device got infected. This happened despite the use of systemic antibiotic, after the surgery, targeting bacteria found in samples. Scar disunion occurred 3 months after implantation. Despite cares, the prosthesis had to be removed 19 months after its implantation without consequences for the patient. At the time of removal, underlying tissues were healed and strong enough to stabilize the chest wall. Removal surgery was easy as the device was used as a dissection plan and the shape allowed to cut the bridges between it and the ribs. No complication occurred after this removal. For the three other patients (\#1, \#3 and \#4), for whom antibiotics were efficient, no infection was observed after a follow-up of 38, 17 and 2 months. None of the patients complain about residual pain or breathe discomfort.

Regarding PFT, after a drop following cardiac surgery (data not shown), there was an improvement over time (Figure 4). 


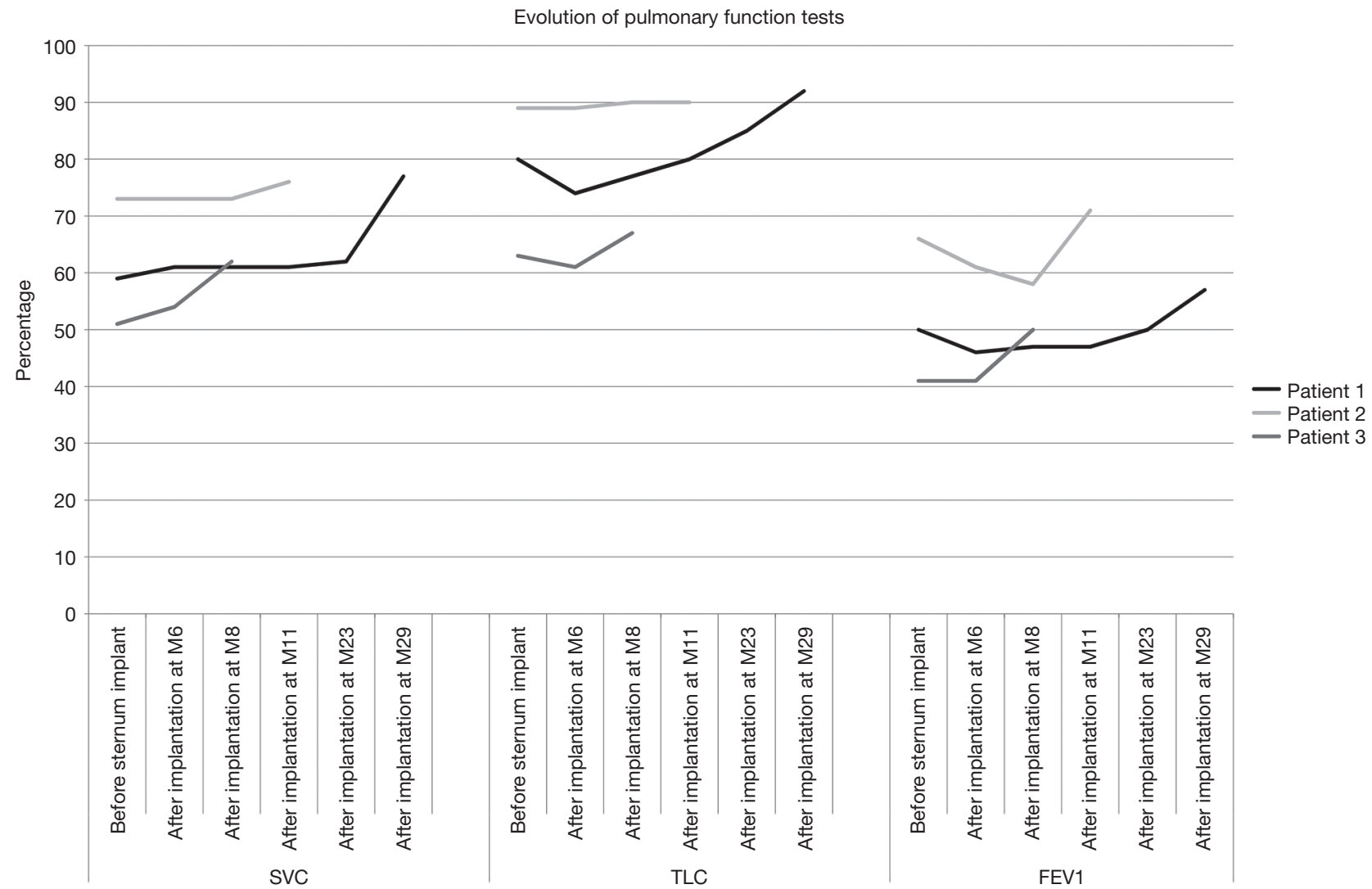

Figure 4 Evolution a pulmonary function tests of the first 3 patients. SVC, slow vital capacity; TLC, total lung capacity; FEV1, forced expiratory volume in 1 second.

\section{Discussion}

DSWI is a rare but life-threatening complication. VAC therapy has changed its evolution but, for some patients, management remains complex. Due to the persistence of infected parts, the use of medical device is not recommended even if sternal stability is improved (17). Therefore, one of the most used techniques relies on muscle flap to cover the diseased sternum. Results are overall good even if some surgical teams report disappointing outcomes $(4,5)$. In some cases like the ones described here, classical therapy is not efficient and patients need sternectomy and reconstruction (18). Several other reconstruction techniques for the sternum are available but none have been widely reported during infection. Allograft is mainly used during reconstruction after cancer (19) as Mesh and titanium bars. Every technique has its own pitfalls and as our, each one is an option but for the moment none can be seen as the "gold standard".

Antibiotic diffusion is very poor in mediastinum
$(14,20,21)$ and might be even worse during DSWI. Local delivery and thus efficient concentrations of antibiotic could circumvent the risk of infection. The antibiotic loaded ceramic allows rapid local protection and for at least 24 hours which covers the beginning of healing after the wound is closed. Even with high dose, comparable to the one injected daily, there is no systemic toxicity as no or very little antibiotic is detected in the blood within the first 48 hours. This was already observed for a chronic osteomyelitis treated with a gentamicin loaded ceramic (9). Locally, no toxicity was reported and these antibiotics are already safely locally administered in several organs without toxicity [orthopedic cement (22), collagen loaded sponges (23)...].

As implantations were performed in an infected area (Table 1), the devices were exposed to a high risk of infection. For patient \#1 and \#3 for whom bacteria were sensitive to gentamicin, no infection occurred. For patient $\# 4$, due to the presence of several bacteria with different resistance a combination of antibiotics was decided. As 
resistances were "pharmacological" ones, the very high local concentration obtained for vancomycin, makes it possible to recover the sensitivity of a bacterium considered as resistant in case of intravenous administration. For patient \#2, the presence of previously unknown resistant bacteria at the time of surgery, due to an ecological change, led to the colonization of the device, as it would have occurred with any "unprotected" device. This unexpected complication, combined with the success of the three other implantations, gives an additional argument in favor of the efficiency of the loaded system. It also advocates performing bacteriological samples as close as possible to the replacement surgery.

Thanks to its biocompatibility and inertness, this prosthetic ceramic sternum was very well tolerated without local discomfort or pain. The follow-up of more than 3 years for the first patient confirms this tolerance. Even for patient \#2 the tolerance of the sternum was satisfying until its removal.

An important point in the follow-up is respiratory function. Patients with muscle flaps surgery may have the persistence of an impaired lung function (24). There are not much papers dealing with that point, but they all find poor results $(6,7,24)$. Morotomi et al. with omental flap found a decrease in the Vital Capacity (7), Nishida et al. using rigid or semi-rigid reconstruction found slight restrictive syndrome (6), and results were the same for Cohen et al. using muscle flaps (24). For the first three patients in this study, PFT follow-up showed an improvement. It could be the consequence of the anchorage mean which allows certain elasticity while maintaining a physiological chest wall motion. It seems that this point could be an advantage of our technique over muscle flaps or mesh and bars.

\section{Conclusions}

Thanks to a long follow-up and absence of infection recurrence or prosthesis rejection for patients \#1, \#3 and \#4 who had an effective protection, we have strong arguments to conclude that the protection offered by the loaded antibiotic is efficient and non-toxic. This antibiotic loaded porous ceramic implant is an interesting option for sternal replacement during DSWI, after or as an alternative to VAC therapy, even if it will not be used for every patient with DSWI, especially those without or with slight destruction of the sternum. The ceramic allows greater chest wall stability than that the one obtained with muscle flaps. Unintentionally, patient \#2 outcome indicates that a non-protected device will fatally fail whereas a protected one, such as for other patients can be successful. Antibiotic loading gives a great security for device implantation. Further implantations are needed to definitively prove the efficacy of this antibiotic(s) loaded ceramic and a clinical trial should begin.

\section{Acknowledgments}

Funding: None.

\section{Footnote}

Conflicts of Interest: F Bertin, E Denes, S El Balkhi: member of the scientific committee of I.Ceram; E Denes: Share holder of I.Ceram. The other authors have no conflicts of interest to declare.

Ethical Statement: The authors are accountable for all aspects of the work in ensuring that questions related to the accuracy or integrity of any part of the work are appropriately investigated and resolved. These surgeries were approved by the ethic committee of the Limoges Teaching Hospital and were allowed by the French Agency for Health Security (Agence Nationale de la Sécurité du Médicament et des produits de santé, ANSM). Patients gave their written consent for the use of this device.

Open Access Statement: This is an Open Access article distributed in accordance with the Creative Commons Attribution-NonCommercial-NoDerivs 4.0 International License (CC BY-NC-ND 4.0), which permits the noncommercial replication and distribution of the article with the strict proviso that no changes or edits are made and the original work is properly cited (including links to both the formal publication through the relevant DOI and the license). See: https://creativecommons.org/licenses/by-nc-nd/4.0/.

\section{References}

1. Yu AW, Rippel RA, Smock E, et al. In patients with poststernotomy mediastinitis is vacuum-assisted closure superior to conventional therapy? Interact Cardiovasc Thorac Surg 2013;17:861-5.

2. Kaul P. Sternal reconstruction after post-sternotomy mediastinitis. J Cardiothorac Surg 2017;12:94.

3. Grapow M, Haug M, Tschung C, et al. Therapy options in deep sternal wound infection: Sternal plating versus muscle flap. PLoS One 2017;12:e180024. 
4. Eriksson J, Huljebrant I, Nettelblad H, et al. Functional impairment after treatment with pectoral muscle flaps because of deep sternal wound infection. Scand Cardiovasc J 2011;45:174-80.

5. Daigeler A, Falkenstein A, Pennekamp W, et al. Sternal osteomyelitis: Long-term results after pectoralis muscle flap reconstruction. Plast Reconstr Surg 2009;123:910-7.

6. Nishida Y, Tsukushi S, Urakawa H, et al. Postoperative pulmonary and shoulder function after sternal reconstruction for patients with chest wall sarcomas. Int J Clin Oncol 2015;20:1218-25.

7. Morotomi N, Saitoh M, Takanashi S, et al. After omental flap transposition, respiratory function and exercise capacity decrease. Ann Thorac Cardiovasc Surg 2010;16:9-15.

8. Bertin F, Piccardo A, Denes E, et al. Porous alumina ceramic sternum: A reliable option for sternal replacement. Ann Thorac Med 2018;13:226-9.

9. Fiorenza F, Durox H, El Balkhi S, et al. Antibiotic-loaded Porous Alumina Ceramic for One-stage Surgery for Chronic Osteomyelitis. J Am Acad Orthop Surg Glob Res Rev 2018;2:e079.

10. Denes E, Barrière G, Poli E, et al. Commentary: Bioceramics and Scaffolds: A Winning Combination for Tissue Engineering. Front Bioeng Biotechnol 2017;5:15-7.

11. Denes E, Barrière G, Poli E, et al. Alumina Biocompatibility. J Long Term Eff Med Implants 2018;28:9-13.

12. Yılmaz EŞ, Aslantaş Ö. Antimicrobial resistance and underlying mechanisms in Staphylococcus aureus isolates. Asian Pac J Trop Med 2017;10:1059-64.

13. Bronner S, Levêque D, Jehl F. Les volumes apparents de distribution des antibiotiques: évaluation, intérêt et limites. Antibiotiques 2006;8:27-38.

14. Martin C, Alaya M, Mallet MN, et al. Penetration of vancomycin into mediastinal and cardiac tissues in humans. Antimicrob Agents Chemother 1994;38:396-9.

Cite this article as: Tricard J, Chermat A, El Balkhi S, Denes E, Bertin F. An antibiotic loaded ceramic sternum to treat destroyed infected sternum: 4 cases. J Thorac Dis 2020;12(3):209-216. doi: 10.21037/jtd.2020.01.70
15. Rybak MJ. The Pharmacokinetic and Pharmacodynamic Properties of Vancomycin. Clin Infect Dis 2006;42:S35-9.

16. The European Committee on Antimicrobial Susceptibility Testing. Breakpoint tables for interpretation of MICs and zone diameters, version 9.0 [Internet]. 2019 [cited 2019 Jul 15]. Available online: http://www.eucast.org/clinical_ breakpoints/

17. Singh K, Anderson E, Harper JG. Overview and Management of Sternal Wound Infection. Semin Plast Surg 2011;25:25-33.

18. Berg LT, Jaakkola P. Kuopio Treatment Strategy after Deep Sternal Wound Infection. Scand J Surg 2013;102:3-8.

19. Marulli G, Dell'amore A, Calabrese F, et al. Safety and Effectiveness of Cadaveric Allograft Sternochondral Replacement After Sternectomy: A New Tool for the Reconstruction of Anterior Chest Wall. Ann Thorac Surg 2017;103:898-905.

20. Martin C, Viviand X, Alaya M, et al. Penetration of ceftriaxone (1 or 2 grams intravenously) into mediastinal and cardiac tissues in humans. Antimicrob Agents Chemother 1996;40:812-5.

21. Mertes PM, Jehl F, Burtin P, et al. Penetration of ofloxacin into heart valves, myocardium, mediastinal fat, and sternal bone marrow in humans. Antimicrob Agents Chemother 1992;36:2493-6.

22. Chang Y, Tai CL, Hsieh PH, et al. Gentamicin in bone cement: A potentially more effective prophylactic measure of infection in joint arthroplasty. Bone Joint Res 2013;2:220-6.

23. Kowalewski M, Pawliszak W, Zaborowska K, et al. Gentamicin-collagen sponge reduces the risk of sternal wound infections after heart surgery: Meta-analysis. J Thorac Cardiovasc Surg 2015;149:1631-40.e1.

24. Cohen M, Yaniv Y, Weiss J, et al. Median sternotomy wound complication: the effect of reconstruction on lung function. Ann Plast Surg 1997;39:36-43. 